\title{
STRUCTURE-ACTIVITY APPROACH IN THE REACTIVATION OF TABUIN-PHOSPHORYLATED HUIMAN ACETYLCHOLINESTERASE WITH BISPYRIDINIUM para-ALDOXIMES
}

\author{
Zrinka KOVARIK, Maja ČALIĆ, Goran ŠINKO, and Anita BOSAK \\ Institute for Medical Research and Occupational Health, Ksaverska cesta 2, \\ HR-10000 Zagreb, Croatia \\ Received in November 2006 \\ Accepted in January 2007
}

\begin{abstract}
We investigated interactions of bispyridinium para-aldoximes $N, N^{\prime}$-(propano)bis(4-hydroxyiminomethyl) pyridinium bromide (TMB-4), $N, N^{\prime}$-(ethano)bis(4-hydroxyiminomethyl)pyridinium methanosulphonate (DMB-4), and $N, N^{\prime}$-(methano)bis(4-hydroxyiminomethyl)pyridinium chloride (MMB-4) with human erythrocyte acetylcholinesterase phosphorylated by tabun. We analysed aldoxime conformations to determine the flexibility of aldoxime as an important feature for binding to the acetylcholinesterase active site. Tabun-inhibited human erythrocyte acetylcholinesterase was completely reactivated only by the most flexible bispyridinium aldoxime - TMB-4 with a propylene chain between two rings. Shorter linkers than propylene (methylene or ethylene) as in MMB-4 and DMB-4 did not allow appropriate orientation in the active site, and MMB-4 and DMB-4 were not efficient reactivators of tabun-phosphorylated acetylcholinesterase. Since aldoximes are also reversible inhibitors of native acetylcholinesterase, we determined dissociation constants and their protective index against acetylcholinesterase inactivation by tabun.
\end{abstract}

KEY WORDS: antidotes, nerve agents, organophosphorus compounds

Progressive inhibition of acetylcholinesterase (AChE; EC 3.1.1.7) by an organophosphorus compound such as the nerve agent tabun is due to the phosphorylation of the active centre serine characterised by the formation of a conjugate and inactivation of this enzyme essential for neurotransmission. A combination of an antimuscarinic agent e.g. atropine and an AChE reactivator such as aldoxime is used for the treatment of organophosphorus compound poisoning. However, despite intense research on reactivation, no aldoxime has been efficient against a variety of agents, because efficiency varies with the structures of both the organophosphorus compound bound and of the reactivator $(1,2)$. Tabun is one of the most potent organophosphorus poisons due to the oxime-resistant reactivation of tabun-phosphorylated acetylcholinesterase. TMB-4 is one of the classical aldoximes and a potent reactivator of AChE inhibited by tabun (cf. 2). Our recent reactivation studies with pyridinium aldoximes, similar to TMB-4, with the para-positioned oxime group gave promising results in reactivating tabun-phosphorylated $\mathrm{AChE}$ and in the therapy of tabun-poisoned mice $(3,4)$. In this paper we continued the in vitro investigation using three known bispyridinium para-aldoximes TMB-4, DMB-4 and MMB-4 with the aim to relate molecular properties of the aldoxime to its reactivation potency. Therefore, we performed the conformational analysis of the aldoximes and determined reactivation rate constants of human erythrocyte AChE inhibited by tabun. Moreover, we determined aldoxime protective potency against $A C h E$ inhibition by tabun, because 
in addition to acting as reactivators, aldoximes are also reversible inhibitors of $\mathrm{AChE}$, and therefore they can protect the catalytic site against phosphorylation due to a direct competition between them and the phosphorylating agent $(5,6)$.

\section{MATERIALS AND METHODS}

\section{Chemicals}

Bispyridinium para-aldoxime $N, N^{\prime}$-(propano)bis(4hydroxyiminomethyl)pyridinium bromide (TMB-4) was obtained from Bosnalijek, Sarajevo, Bosnia and Herzegovina; $N, N^{\prime}$ '-(ethano)bis(4-hydroxyiminomethyl)pyridinium methanosulphonate (DMB-4) and $N, N^{\prime}$-(methano)bis(4-hydroxyiminomethyl)pyridinium chloride (MMB-4) were obtained from the US Army Medical Research Institute of Chemical Defense, Aberdeen Proving Ground, MD, USA. Aldoximes were kept at room temperature and dissolved in water immediately before use. Tabun was purchased from NC Laboratory, Spiez, Switzerland. Acetylthiocholine iodide (ATCh) and 5,5'-dithiobis(2-nitrobenzoic acid) (DTNB) were purchased from Sigma Chemical Co., St. Louis, MO, USA.

\section{Conformational analysis of aldoximes}

Conformational analysis (Table 1) was performed using MM2 and semi-empirical calculations with MOPAC 2000 software (PM-3 method with COSMO solvation model) created by J.J.P. Stewart (Fujitsu Ltd., Tokyo, Japan, 1999) according to published procedures $(7,8)$.

\section{AChE activity measurement}

Native non-haemolysed human erythrocytes were the source of $\mathrm{AChE}$; the final dilution during enzyme assay was 400 -fold. All experiments were done in $0.1 \mathrm{~mol} \mathrm{~L}^{-1}$ sodium phosphate buffer, $\mathrm{pH}$ 7.4 , at $25^{\circ} \mathrm{C}$. The enzyme activity was measured spectrophotometrically according to the Ellman procedure (9) with the thiol reagent DTNB (0.3 mmol L-1 final concentration) and the substrate ATCh. The increase in absorbance was read at $436 \mathrm{~nm}$ for $1 \mathrm{~min}$. All spectrophotometric measurements were performed on a CARY 300 spectrophotometer (Varian Inc., Australia).

\section{Reactivation of tabun-inhibited AChE}

Undiluted erythrocytes were incubated with $5 \mu \mathrm{mol} \mathrm{L}-1$ tabun up to 60 min achieving $90 \%$ to $100 \%$

Table 1 Energy barriers (E, $\mathrm{kcal} \mathrm{mol}^{-1}$ ) for rotation around single bonds in tested aldoximes. Energies were calculated using the MM2 method. Asterisk denotes averaged value due to symmetry in the molecule.

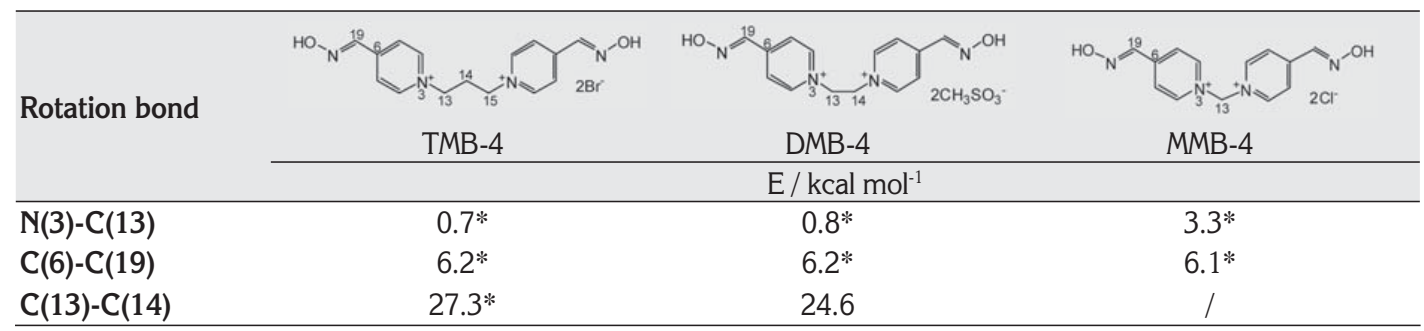

Table 2 Reactivation of tabun-inhibited human erythrocyte acetylcholinesterase by tested aldoximes. Constants ${ }^{a}$ ( \pm standard errors) are calculated by Eqns. 1-3 from $k_{\text {obs }}$ constants obtained in at least three experiments. The maximal percent of reactivation (React ${ }_{\text {max }}$ ) measured within the specified time of the experiment is also given.

\begin{tabular}{lccccc}
\hline Aldoxime $\left(\mathrm{mmol} \mathrm{L}^{-1}\right)$ & $\boldsymbol{k}_{+2} / \mathrm{min}^{-1}$ & $K_{\mathrm{ox}} / \mathrm{mmol} \mathrm{L}^{-1}$ & $\boldsymbol{k}_{\mathrm{r}} / \mathrm{L} \mathrm{mol}^{-1} \mathrm{~min}^{-1}$ & React $_{\max } / \%$ & Time \\
\hline TMB-4 (0.05-10.0) & $0.15 \pm 0.016$ & $0.49 \pm 0.17$ & $306 \pm 131$ & 100 & $20 \mathrm{~min}$ \\
DMB-4 (0.1-3.0) & $0.002 \pm 0.0001$ & $0.048 \pm 0.015$ & $41.7 \pm 13.2$ & 70 & $16 \mathrm{~h}$ \\
MMB-4 (0.1-3.0) & $0.004 \pm 0.0004$ & $0.28 \pm 0.10$ & $14.3 \pm 5.30$ & 80 & $10 \mathrm{~h}$ \\
\hline
\end{tabular}

${ }^{a} k_{+2}$ - the maximum first order reactivation rate constant; $k_{r}$ - the overall second order reactivation rate constant; $K_{o x}$ - the dissociation constant of the phosphorylated enzyme and oxime 
inhibition. Incubation mixture was diluted 10 times with $0.1 \mathrm{~mol} \mathrm{~L}^{-1}$ phosphate buffer, $\mathrm{pH} 7.4$, containing the aldoxime to start the reactivation. Final aldoxime concentrations used for the reactivation of tabuninhibited AChE are given in Table 2. After a given time of reactivation aliquots were diluted 40 times, DTNB and ATCh (1.0 mmol L-1 final concentration) were added, and the enzyme activity was measured. An equivalent sample of uninhibited enzyme was diluted to the same extent as the inhibited AChE, and control activity was measured in the presence of the aldoxime at concentrations used for reactivation. Both the activities of control and reactivation mixture were corrected for the oxime-induced hydrolysis of ATCh. No spontaneous reactivation of the phosphorylated enzyme took place.

Oxime-assisted reactivation of phosphorylated AChE proceeds according to Scheme 1 :

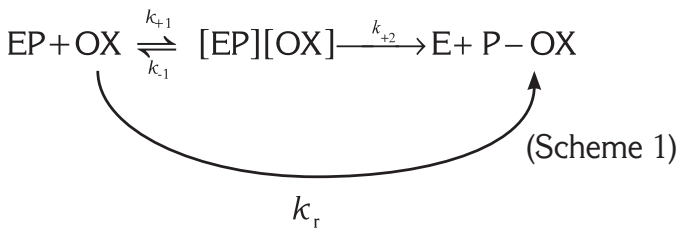

where EP is the phosphorylated enzyme, $[E P][O X]$ is the reversible Michaelis type complex between EP and the aldoxime (OX), E is the active enzyme, P-OX is the phosphorylated aldoxime, $k_{+2}$ is the maximum first order rate constant, and $k_{\mathrm{r}}$ is the overall second order rate constant of reactivation. Scheme 1 is defined by the following equation:

$\operatorname{In} \frac{[\mathrm{EP}]_{0}}{[\mathrm{EP}]_{\mathrm{t}}}=\frac{k_{+2} \cdot[\mathrm{OX}]}{K_{\mathrm{OX}}+[\mathrm{OX}]} \cdot \mathrm{t}=k_{\mathrm{obs}} \cdot \mathrm{t}$

(Eqn. 1)

where $[E P]_{0}$ and $[E P]_{t}$ are the concentrations of the phosphorylated enzyme at time zero and at time $t$, respectively. $K_{\mathrm{OX}}$ is equal to the ratio $\left(k_{-1}+k_{+2}\right) / k_{+1}$, and it approximates the dissociation constant of the $[E P][O X]$ complex. $k_{\text {obs }}$ is the observed first-order rate constant of reactivation at a given aldoxime concentration. The overall second-order rate constant of reactivation $\left(k_{\mathrm{r}}\right)$ is the ratio

$k_{\mathrm{r}}=\frac{k_{+2}}{K_{\mathrm{OX}}}$

Experimental data were presented as the percentage of reactivation

\% Reactivation $=\frac{v_{(\mathrm{EP}+\mathrm{OX})_{t}}}{v_{(\mathrm{E}+\mathrm{OX})}} \cdot 100$

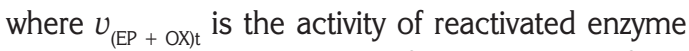
at time $t$, and $v_{(\mathrm{E}+\mathrm{Ox})}$ stands for the activity of the enzyme incubated with aldoxime. Since (100-\% Reactivation) is equal to $100[E P]_{\mathrm{r}} /[\mathrm{EP}]_{0}$, one can relate the experimental data to Eqn. 1. At each aldoxime concentration, $k_{\text {obs }}$ was calculated from the slope of the initial portion of log (100-\% Reactivation) us. time of reactivation. Reactivation with each aldoxime followed Eqn. 1. Therefore, $k_{+2}$ and $K_{\mathrm{ox}}$ were obtained by the non-linear fit of the relationship between $k_{\text {obs }} u S$. [OX], while $k_{\mathrm{r}}$ was calculated using Eqn. 2.

\section{Reversible inhibition of $A C h E$}

Reversible inhibition of AChE by aldoximes was measured in a medium which contained erythrocytes suspended in buffer, DTNB, aldoxime, and ATCh. Aldoxime and substrate concentrations are given in Table 3.

The inhibition constants were evaluated from the effect of substrate concentration (s) on the degree of inhibition according to the equation:

Table 3 Reversible inhibition of human erythrocyte acetylcholinesterase by the aldoximes, protection with aldoximes $\left(0.2 \mathrm{mmol} \mathrm{L}^{-1)}\right.$ against phosphorylation of human erythrocyte acetylcholinesterase by tabun and non-enzymatic reaction of the acetylthiocholine with tested aldoximes (constants \pm standard errors, protective index \pm standard deviation).

\begin{tabular}{lccccccc}
\hline $\begin{array}{l}\text { Aldoxime } \\
\left(\mathrm{mmol} \mathrm{L}^{-1}\right)\end{array}$ & $\begin{array}{c}\text { ATCh } / \\
\mathrm{mmol} \mathrm{L}^{-1}\end{array}$ & $\begin{array}{c}K_{\mathrm{i}} / \\
\mathrm{mmol} \mathrm{L}\end{array}$ & $\begin{array}{c}K_{(\mathrm{S})} / \\
\mathrm{mmol} \mathrm{L}^{-1}\end{array}$ & $\begin{array}{c}K_{\mathrm{itheor}} / \\
\mathrm{mmol} \mathrm{L}^{-1}\end{array}$ & $\mathrm{PI}$ & $\begin{array}{c}\mathrm{PI}_{\text {theor }} \\
\mathrm{L} \mathrm{mol}^{-1} \mathbf{c m}^{-1}\end{array}$ \\
\hline TMB-4 (0.1-0.7) & $0.05-0.7$ & $0.18 \pm 0.01$ & $0.96 \pm 0.16$ & 0.13 & $2.6 \pm 0.0$ & 2.1 & $31 \pm 0$ \\
DMB-4 (0.05-0.5) & $0.1-1.0$ & $0.10 \pm 0.02$ & $0.74 \pm 0.19$ & 0.12 & $2.7 \pm 0.4$ & 3.0 & $29 \pm 1$ \\
MMB-4 (0.25-0.7) & $0.1-1.0$ & $0.49 \pm 0.07$ & $0.48 \pm 0.09$ & 0.40 & $1.5 \pm 0.1$ & 1.4 & $32 \pm 1$ \\
\hline
\end{tabular}

$K_{i}$ and $K_{(s)}$ - the dissociation constant of the enzyme and oxime complex and of the enzyme and substrate complex, respectively; $K_{i \text { theor }}-$ theoretically determined $K_{i}$ by Eqn. 7; PI and PI ${ }_{\text {theor }}$ - experimentally and theoretically determined protective index; $k_{N E}$ - the second-order rate constant of the non-enzymatic reaction 
$K_{\text {app }}=\frac{v_{\mathrm{i}} \cdot i}{v_{0}-v_{\mathrm{i}}}=K_{\mathrm{i}}+\frac{K_{\mathrm{i}}}{K_{(\mathrm{S})}} \cdot \mathrm{s}$

(Eqn. 4)

$K_{\text {app }}$ is the apparent enzyme-aldoxime dissociation constant at a given substrate concentration ( $(s)$, calculated from enzyme activities $v_{0}$ and $v_{\mathrm{i}}$, measured in the absence and in the presence of the aldoxime (i), respectively. $K_{i}$ is the enzyme-aldoxime dissociation constant of a complex formed in the catalytic site, and $K_{(\mathrm{S})}$ is the enzyme-substrate dissociation constant which should correspond to the Michaelis constant $\left(K_{M}\right)$, if aldoxime binds only to the catalytic site.

\section{Protection of AChE against phosphorylation}

Protection of AChE against phosphorylation was measured in a medium which contained erythrocytes suspended in $0.1 \mathrm{~mol} \mathrm{~L}^{-1}$ phosphate buffer, DTNB, aldoxime $\left(0.2 \mathrm{mmol} \mathrm{L}^{-1}\right)$, and tabun $\left(100 \mathrm{nmol} \mathrm{L}^{-1}\right)$. After a given time of inhibition (up to $5 \mathrm{~min}$ ), ATCh (1.0 mmol L-1 final concentration) was added and the increase in absorbance was read for $1 \mathrm{~min}$. Control samples contained no aldoxime.

The second-order rate constant of inhibition by tabun $\left(k_{i}\right)$ was calculated from the equation:

$\ln \frac{v_{0}}{v_{\mathrm{OP}}}=k_{\mathrm{i}} \cdot[\mathrm{OP}] \cdot \mathrm{t}$

(Eqn. 5)

where $v_{\mathrm{OP}}$ and $v_{0}$ are enzyme activities with and without the organophosphorus compound, respectively; OP is the concentration of tabun, and $t$ is time of inhibition. Protection was expressed in terms of protective index (PI) which corresponds to the ratio:

$\mathrm{PI}=\frac{k_{\mathrm{i}}}{k_{\mathrm{i}}^{\prime}}$

(Eqn. 6)

The second-order rate constant of inhibition in the presence of the aldoxime $\left(k_{i}^{\prime}\right)$ was calculated using Eqn. 5 where $v_{0}$ and $v_{\mathrm{OP}}$ denote enzyme activities in the absence of both the aldoxime and organophosphorus compound, and in their presence, respectively.

Protective indexes for all tested aldoximes were also determined theoretically from:

$$
\mathrm{PI}_{\text {theor }}=1+i / \mathrm{K}_{\mathrm{i}}
$$

where $i$ stands for aldoxime concentration, and $K$ is the experimentally determined enzyme-aldoxime dissociation constant.

\section{Oxime-catalysed hydrolysis of acetylthiocholine}

The reaction of ATCh with aldoxime was measured for $1 \mathrm{~min}$ in a medium which contained ATCh, aldoxime, DTNB and $0.1 \mathrm{~mol} \mathrm{~L}^{-1}$ phosphate buffer,
$\mathrm{pH} 7.4$ at $25^{\circ} \mathrm{C}$. Aldoxime and ATCh concentrations are given in Table 3. Two to four measurements were done with each ATCh/aldoxime concentration pair. The second-order rate constant of the nonenzymatic reaction $\left(k_{\mathrm{NE}}\right)$ was calculated according to the following equation:

$$
\mathrm{C} / \mathrm{t}=k_{\mathrm{NE}} \cdot s \cdot i
$$

where $C$ is the released thiocholine concentration, $t$ is the time of reaction, and $s$ and $i$ are the initial ATCh and aldoxime concentrations. The thiocholine concentration was calculated from the absorbance monitored at $436 \mathrm{~nm}\left(\varepsilon_{\mathrm{M}}=11000 \mathrm{~L} \mathrm{~cm}^{-1} \mathrm{~mol}^{-1} ; 10\right)$.

\section{RESULTS AND DISCUSSION}

Flexibility of aldoxime molecule is important for binding to AChE, i.e. for appropriate oxime group orientation towards phosphorylated catalytic serine. Therefore, we performed the conformational analysis of the aldoximes to relate their molecular properties to the studied AChE interactions. Table 1 shows the energy barriers for rotation around single bonds in tested oximes, while the superposition of minimized aldoxime structures is presented in Figure 1. Aldoximes TMB-4 and DMB-4 were more flexible than MMB-4 due to the lower rotation barrier of the $\mathrm{N}(3)-\mathrm{C}(13)$ bond. A higher rotation barrier in MMB-4 was probably caused by the steric hindrance of two pyridinium rings connected by a short linker. Pyridinium rings of MMB-4 are stabilised at an angle of about $90^{\circ}$, and for their rotation additional energy is required. Actually, we have recently shown that

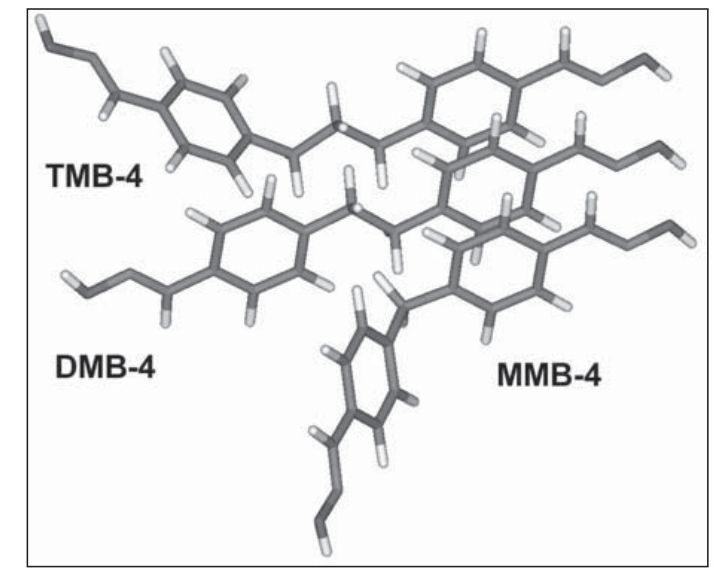

Figure 1 Superposition of minimised structures of para-aldoximes. Hydrogen atoms are not shown for better visibility. 
the rotation barrier of $\mathrm{N}(3)-\mathrm{C}(13)$ bond distinguishes para- from ortho-pyridinium aldoximes: 0.7 us. 15 $\mathrm{kcal} \mathrm{mol}^{-1}(11)$. However, the rotation of the parapositioned oxime groups around the bond $\mathrm{C}(6)-\mathrm{C}(19)$ was similar in all three aldoximes. Bonds in the linker connecting atoms numbered 13 and 14 , and atoms 14 and 15 with the highest rotation energy barriers, determined the overall aldoxime rigidness. Very likely because of the linker rigidness, TMB-4 and DMB-4 sterically better fitted the $\mathrm{AChE}$ active site gorge than MMB-4, as was shown in a previous docking study of aldoximes similar to MMB-4 (12).

Table 2 shows the kinetic parameters for the reactivation of tabun-inhibited human AChE by the aldoximes, and one representative experiment is

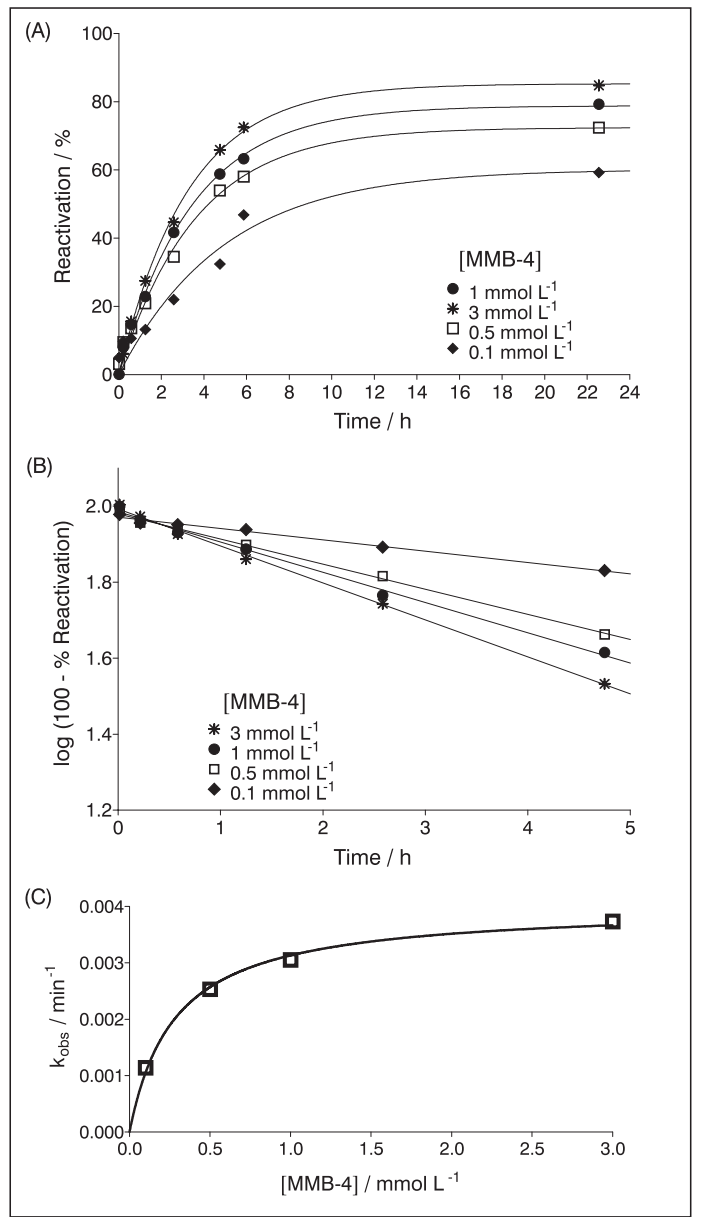

Figure 2 Reactivation of tabun-inhibited human erythrocyte AChE by MMB-4. (A) A single data point indicates calculated percent of reactivation using Eqn. 3. (B) Slopes of the reactivation curve yield $k_{\text {obs }}$ constants. (C) $k_{\text {obs }}$ is plotted as a function of MMB-4 and the curve is fitted using Eqn. 1.

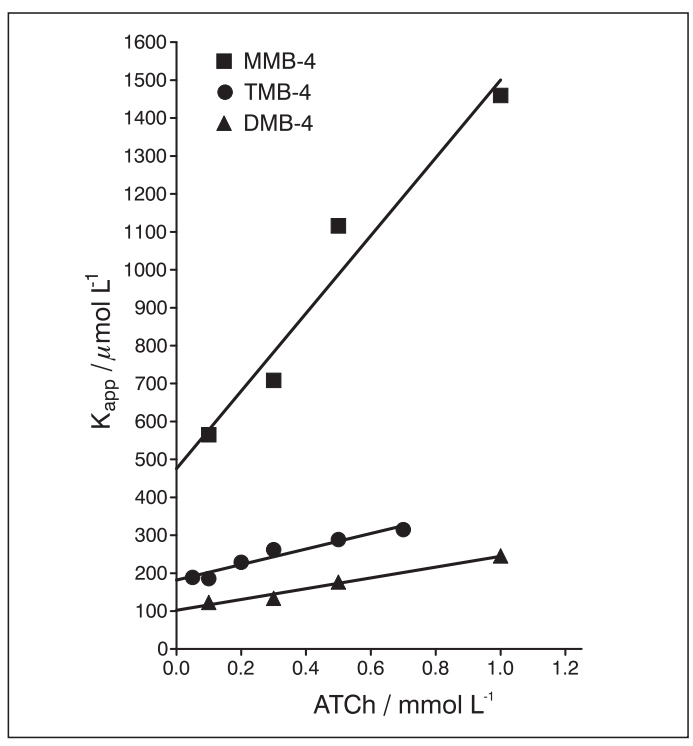

Figure 3 Reversible inhibition of human erythrocyte AChE by the aldoximes. Points indicate the calculated average $K_{\text {app }}$ from measured activities with acetylthiocholine in the presence of aldoximes using Eqn. 4. Lines represent linear regression analysis and y-intercepts represent $K_{i}$ constants.

shown in Figure 2. Only TMB-4 completely restored the enzyme activity. The overall reactivation rate of TMB-4 was the highest, primarily due to its fastest first-order reactivation rate. A relatively high percentage of maximum reactivation by $\mathrm{DMB}-4$ and MMB-4 was slowly obtained after more than 10 hours. However, the reactivation by DMB-4 and MMB-4 was not complete, and the kinetics at longer time intervals deviated from the first-order process described in Eqn. 1. This deviation could be due to a fraction of the aged phosphorylated enzyme (due to the post-inhibitory dealkylation known as aging) and/or re-inhibition of the active enzyme by the phosphorylated oxime (13). It is known that the aging of tabun-inhibited human $\mathrm{AChE}$ is relatively slow $\left(\mathrm{t}_{0.5}=13 \mathrm{~h} ; 14\right)$. Although no data on the stability or inhibitory potency of tabun phosphorylated DMB-4 or MMB-4 are available in literature, the conjugate of tabun and monopyridinium para-aldoxime 4-PAM was a poor inhibitor of $\mathrm{AChE}$, which was attributed to a combination of steric factors and a reduction in the electro-positivity of the phosphorus atom (15). Since three aldoximes differ only in the length of the chain between pyridinium rings, we attributed the low efficiency of MMB-4 in reactivation to its molecular properties discussed above. We showed earlier that the flexible bispyridinium para-aldoxime 


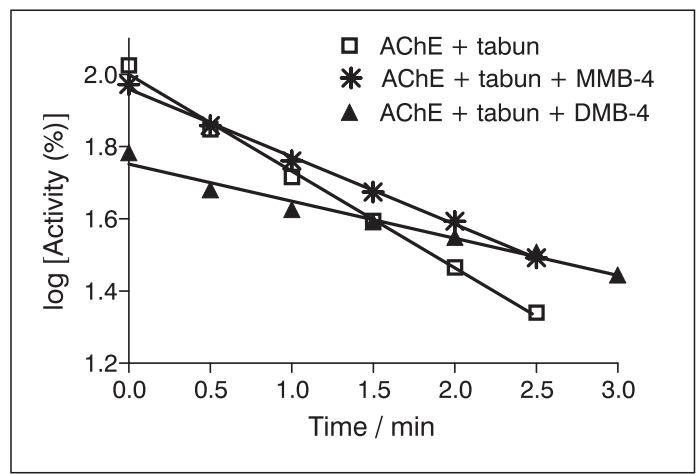

Figure 4 Progressive inhibition of AChE by tabun in the absence and in the presence of aldoximes $\left(0.2 \mathrm{mmol} \mathrm{L}^{-1}\right)$ wherefrom protective indexes were determined. Slopes represent the first-order inhibition rate constants.

with a butylene chain was a very potent reactivator of tabun-inhibited AChE $(3,11)$. However, potent reactivators were also butylene-linked bisoximes that instead of pyridinium had imidazolium rings (16). Indeed, bispyridinium para-aldoxime with shorter linker than propylene and longer than butylene or monopyridinium para-aldoximes were not effective tabun-phosphorylated reactivators $(12,17,18)$. A reactivation study of diisopropylphosphoryl-AChE showed that the most promising bispyridinium paraaldoxime was a propylene-linked bisaldoxime, while the most promising bispyridinium ortho-aldoxime was a heptylene-linked bisaldoxime (19). Crystal structures of complexes explained different requirements of the chain length for reactivation. This means that the most potent reactivators should span the active site of the phosphorylated $\mathrm{AChE}$ and pyridinium rings should be stabilised by aromatic residues in the peripheral site and choline binding site of AChE (20).

Since aldoximes are also reversible inhibitors of AChE, we determined the dissociation constants of aldoxime-human erythrocyte AChE complex (Table 3). Over the studied concentration range of acetylthiocholine, aldoxime binding to the catalytic site was competitive as shown in Figure 3. The catalytic site of AChE showed the highest affinity (lowest $K_{\mathrm{i}}$ ) for DMB-4, about five times higher than that for MMB-4. The determined $K_{\mathrm{i}}$ constants for DMB-4 and TMB-4 were similar to constants published for other bispyridinium compounds (3), while for MMB- $4 K$ was similar to $K_{\mathrm{i}}$ of monopyridinium aldoxime, 4-PAM (19), showing that the second ring in MMB-4 does not improve stabilisation of aldoxime binding. The $K_{(\mathrm{S})}$ values, derived from the kinetics of inhibition with aldoximes were higher, but close to the previously determined $K_{M}(21)$. This supports our belief that the determined $K_{\mathrm{i}}$ constants correspond to binding to the catalytic site of AChE. Higher substrate concentrations could not be used to determine possible aldoxime binding to the peripheral site of AChE because all three aldoximes reacted with acetylthiocholine, and this reaction interfered with the enzyme assay. Namely, the oxime group reacts with AChE substrate acetylthiocholine on a 1:1 molar basis, and thiocholine is one of the reaction products $(11,22)$. The rate constants for aldoxime-catalysed hydrolysis of acetylthiocholine are given in Table 3. Constants were similar to the rate constant obtained for LüH-6 (obidoxime), a bis-pyridinium aldoxime (23).

The binding affinity of the aldoximes to the free enzyme did not correlate with aldoxime efficacy in enzyme reactivation (cf. Table 2). The phosphorylated AChE had a higher affinity for DMB-4 and MMB-4 than free enzyme, i.e. $K_{\mathrm{oX}}$ constants were about two times lower than the respective $K_{\mathrm{i}}$. It seems that reactivation primarily depends on the displacement rate of the phosphorus moiety, because aldoxime with a high binding affinity could be stabilised far from the phosphorus atom. Relevant enzyme-aldoxime dissociation constant should perhaps be determined before starting reactivation experiments, because it might indicate the binding affinity of phosphorylated enzyme, which is expected to be lower (24).

As reversible inhibitors, aldoximes can protect the catalytic serine against phosphorylation, which means that even though oxime-mediated reactivation is poor, aldoximes could be used as prophylactic agents (4). Therefore, we measured progressive tabun inhibition of AChE in the absence and in the presence of aldoximes, and calculated protective indexes (PI; Table 3). All tested aldoximes $\left(0.2 \mathrm{mmol} \mathrm{L}^{-1}\right)$ protected the enzyme from phosphorylation by tabun (Figure 4). As one could expect, MMB-4 showed a limited protection ability because MMB-4 concentration of $0.2 \mathrm{mmol} \mathrm{L}^{-1}$ is less than a half its $K_{i}$. Protective indexes for all tested aldoximes were also evaluated theoretically because the relationship between experimentally and theoretically obtained protective indexes could be used to determine the aldoxime binding site in AChE (25) and/or $K_{\mathrm{i}}$ constants. Experimentally obtained PI corresponded to the theoretically obtained $\mathrm{PI}_{\text {theor }}$, and so did $K_{\mathrm{i}}$ and $K_{\mathrm{itheor}}$ (cf. Table 3). Therefore, aldoximes protected the enzyme primarily by binding to the catalytic site. 
In conclusion, the relationship between aldoxime potency to reactivate tabun-inhibited $\mathrm{AChE}$ and the length of its linker between two pyridinium rings, shown in this paper, confirmed previous related studies $(17,19)$. The potency of bispyridinium para-aldoxime to reactivate tabun-phosphorylated $\mathrm{AChE}$ decreases with its linker length, and the optimum length is three or four $\mathrm{CH}_{2}$ groups. We analysed aldoxime conformations to determine their flexibility as an important feature for binding to acetylcholinesterase active site. MMB-4 was the least flexible aldoxime, and showed limited reactivation potency. The most flexible and potent reactivator of tabun-phosphorylated AChE was TMB-4, which had the ability for nucleophilic attack, probably due to the stabilisation of the oxime group close to the phosphorus of the phosphorylated catalytic centre of AChE.

\section{Acknowledgement}

We wish to thank Dr Irwin Koplovitz (US Army Medical Research Institute of Chemical Defense, Aberdeen Proving Ground, MD, USA) and Professor Palmer Taylor (University of California at San Diego, La Jolla, CA, USA) for supplying us with aldoximes MMB4 and DMB-4. This work was supported by the NATO Reintegration Grant and by the Croatian Ministry of Science, Education and Sports Grant.

\section{REFERENCES}

1. Gray AP. Design and structure-activity relationships of antidotes to organophosphorus anticholinesterase agents. Drug Metab Rev 1984;15, 557-89.

2. Stojiljković MP, Jokanović M. Pyridinium oximes: rationale for their selection as causal antidotes against organophosphate poisonings and current solutions for auto-injectors. Arh Hig Rada Toksikol 2006;57:43543.

3. Čalić M, Lucić Vrdoljak A, Radić B, Jelić D, Jun D, Kuča K, Kovarik Z. In vitro and in vivo evaluation of pyridinium aldoximes: mode of interaction with acetylcholinesterase, effect on tabun- and somanpoisoned mice and their cytotoxicity. Toxicology 2006;219:85-96.

4. Lucić Vrdoljak A, Čalić M, Radić B, Berend S, Jun D, Kuča K, Kovarik Z. Pretreatment with pyridinium aldoximes improves antidotal therapy against tabun poisoning. Toxicology 2006;228:41-50.

5. Simeon-Rudolf V, Reiner E, Škrinjarić-Špoljar M, Radić B, Lucić A, Primožič I, Tomić S. Quinuclidinium- imidazolium compounds: synthesis, mode of interaction with acetylcholinesterase and effect upon soman intoxicated mice. Arch Toxicol 1998;72:28995.

6. Škrinjarić-Špoljar M, Burger N, Lovrić J. Inhibition of acetylcholinesterase by three new pyridinium compounds and their effect on phosphonylation of the enzyme. J Enzym Inhib 1999;14:331-41.

7. Kovarik Z, Bosak A, Šinko G, Latas T. Exploring active sites of cholinesterases by inhibition with bambuterol and haloxon. Croat Chem Acta 2003;76:63-7.

8. Šinko G, Bosak A, Kovarik Z, Simeon-Rudolf V. Structure-inhibition relationships in the interaction of butyrylcholinesterase with bambuterol, haloxon and their leaving groups. Chem-Biol Interact 2005;157158:421-3.

9. Ellman GL, Courtney KD, Andres VJr, Featherstone RM. New and rapid colorimetric determination of acetylcholinesterase activity. Biochem Pharmacol 1961;7:88-95.

10. Eyer P, Worek F, Kiderlen D, Šinko G, Štuglin A, SimeonRudolf $\mathrm{V}$, Reiner E. Molar absorption coefficients for the reduced Ellman reagent: reassessment. Anal Biochem 2003;312:224-7.

11. Šinko G, Čalić M, Kovarik Z. para- and ortho-Pyridinium aldoximes in reaction with acetylthiocholine. FEBS Lett 2006;580:3167-72.

12. Odžak R, Čalić M, Hrenar T, Primožič I, Kovarik Z. Evaluation of monoquaternary pyridinium aldoximes potency to reactivate tabun-inhibited human acetylcholinesterase. Toxicology 2006;233:85-96.

13. KovarikZ, RadićZ, Berman HA, Simeon-RudolfV, Reiner E, Taylor P. Mutant cholinesterases possessing enhanced capacity for reactivation of their phosphonylated conjugates. Biochemistry 2004;43:3222-9.

14. Heilbronn E. In vitro reactivation and "aging" of tabun-inhibited blood cholinesterases studied with N-methyl-pyridinium-2-aldoxime methane sulphonate and $\mathrm{N}, \mathrm{N}$ '-trimethylene bis (pyridinium-4-aldoxime) dibromide. Biochem Pharmacol 1963;12:25-36.

15. Ashani Y, Bhattacharjee AK, Leader H, Saxena A, Doctor BP. Inhibition of cholinesterase with cationic phosphonyl oximes highlights distinctive properties of the charged pyridine groups of quaternary oxime reactivators. Biochem Pharmacol 2003;33:191-202.

16. Francisković L, Škrinjarić-Špoljar M, Reiner E. Interaction of imidazolium and pyridinium dioximes with human erythrocyte acetylcholinesterase. ChemBiol Interact 1993;87:323-8.

17. Kuča K, Patočka J, Cabal J. Reactivation of organophosphate inhibited acetylcholinesterase activity by $\alpha, \omega$-bis-(hydroxyiminomethylpyridinium)alkanes in vitro. J Appl Biomed 2003;1:207-11.

18. Worek F, Thiermann H, Szinicz L, Eyer P. Kinetic analysis of interactions between human acetylcholineserase, structurally different organophosphorus compounds 
and aldoximes. Biochem Pharmacol 2004;68:223748.

19. Pang Y-P, Kollmeyer TM, Hong F, Lee J, Hammond PI, Haugabouk SP, Brimijoin S. Rational design of alkylene-linked bis-pyridiniumaldoximes as improved acetylcholinesterase reactivators. Chem Biol 2003;10:491-502.

20. Ekström F, Pang Y-P, Boman M, Artursson E, Akfur C, Börjegren S. Crystal structures of acetylcholinesterase in complex with HI-6, Ortho-7 and obidoxime: Structural basis for differences in the ability to reactivate tabun conjugates. Biochem Pharmacol 2006;72:597-607.

21. Bosak A, Primožič I, Oršulić M, Tomić S, Simeon-Rudolf $\mathrm{V}$. Enantiomers of quinuclidin-3-ol derivates: resolution and interactions with human cholinesterases. Croat Chem Acta 2005;78:121-8.
22. Simeon V, Radić Z, Reiner E. Inhibition of cholinesterase by the aldoximes P2AM and toxogonin. Croat Chem Acta 1981;54:473-80.

23. Škrinjarić-Špoljar M, Simeon V, Reiner E, Krauthacker B. Bispyridinium compounds: inhibition of human erythrocyte acetylcholinesterase and protection of the enzyme against phosphylation. Acta Pharm Jugosl 1988;38:101-9.

24. Kovarik Z, Ciban N, Radić Z, Simeon-Rudolf V, Taylor P. Active site mutant acetylcholinesterase interactions with 2-PAM, HI-6, and DDVP. Biochem Biophys Res Commun 2006;342:973-8.

25. Reiner E. Inhibition of acetylcholinesterase by 4,4'bipyridine and its effect upon phosphylation of the enzyme. Croat Chem Acta 1986;59:925-31. 


\section{Sažetak}

\section{ODNOS STRUKTURE I AKTIVNOSTI U REAKTIVACIJI TABUNOM FOSFORILIRANE LJUDSKE ACETILKOLINESTERAZE BISPIRIDINIJEVIM para-ALDOKSIMIMA}

Proučavali smo interakcije bispiridinijevih para-oksima $N, N^{\prime}$-(propano)bis(4-hidroksiiminometil)piridinijeva bromida (TMB-4), $N, N^{\prime}$-(etanano)bis(4-hidroksiiminometil)piridinijeva metanosulfonata (DMB-4) i $N, N^{\prime}$ (metano)bis(4-hidroksiiminometil)piridinijeva klorida (MMB-4) s ljudskom eritrocitnom acetilkolinesterazom fosforiliranom tabunom. Da bismo odredili fleksibilnosti aldoksima, što je važna osobina kod njihova vezanja u aktivno mjesto acetilkolinesteraze, analizirali smo i konformacijske odlike aldoksima. Ljudska acetilkolinesteraza inhibirana tabunom bila je potpuno reaktivirana samo najfleksibilnijim bispiridinijevim aldoksimom - TMB-4. Aldoksimi MMB-4 i DMB-4 nisu bili efikasni reaktivatori acetilkolinesteraze fosforilirane tabunom jer je kod tih spojeva lanac koji povezuje dva prstena kraći od propilena (metilen u MMB-4 i etilen u DMB-4), što ne dopušta povoljnu orijentaciju tih aldoksima unutar aktivnog mjesta enzima. S obzirom na to da su aldoksimi i reverzibilni inhibitori nativne acetilkolinesteraze, odredili smo njihove disocijacijske konstante, kao i zaštitu acetilkolinesteraze od inhibiranja tabunom reverzibilnim vezanjem aldoksima.

KLJUČNE RIJEČI: antidoti, organofosforni spojevi, živčani bojni otrovi

\section{CORRESPONDING AUTHOR:}

Zrinka Kovarik, Ph.D.

Institute for Medical Research and Occupational Health P.O. Box 291, HR-10001 ZAGREB, Croatia

E-mail: zkovarik@imi.hr 